\title{
The frequency of channel-forming discharges in a tributary of Upper Big Walnut Creek, Ohio
}

\author{
B.E. Fry, A. Ward, and K.W. King
}

\begin{abstract}
Understanding floodplain hydrology is necessary to interpret water quality and properly identify and predict the effectiveness of conservation practices in headwater watersheds. The goal of this study was to determine the frequency and magnitude of out-of-bank and channel-forming discharges in Sugar Creek, a tributary of the Upper Big Walnut Creek, in Ohio. To address this goal, a stream geomorphology study was conducted, measured discharge data at a downstream location were used to develop a calibrated discharge versus recurrence interval relationship, and the Hydrologic Engineering Center's Hydrologic Modeling System (HEC-HMS) and River Analysis System (HEC-RAS) simulation models were used to develop out-of-bank discharge recurrence interval relationships for selected locations along Sugar Creek. Much of Sugar Creek was in dynamic equilibrium and had an extensive floodplain with entrenchment ratios ranging from 2 to 18 . At the eight locations studied, two experienced bankfull or larger discharges an average of 12 times per year, with an approximate 0.2-year recurrence interval. Seventy-five percent of the locations experienced bankfull or larger discharges an average of at least 3 times per year, with an approximate 0.8 year recurrence interval. All of the locations experienced out-of-bank discharges an average of at least once per year, with the 2 -year recurrence interval discharge. The annual outof-bank discharges at each location ranged from $0.4 \%$ to $13 \%$ of the average annual flow volume. Based on the results, we recommended that research be conducted in the Sugar Creek Watershed to quantify the water quality benefits of a system in dynamic equilibrium and a well-attached, active floodplain.
\end{abstract}

Key words: bankfull discharge-dynamic equilibrium—-floodplain connectivity—stream geomorphology

\begin{abstract}
As part of the Conservation Effect Assessment Project, the USDA Agricultural Research Service (USDA ARS) is conducting a project to quantify the benefits of USDA conservation programs (Richardson et al. 2008; King et al. 2008). Conservation programs being evaluated include the Conservation Reserve Program, the Environmental Quality Incentive Program, and the Conservation Security Program. These programs define which agricultural best management practices (BMPs) are eligible for government cost share payments. Watershed scale assessments of BMPs are taking place in twelve benchmark watersheds, where detailed assessments will provide the framework for a national model.
\end{abstract}

attempted to quantify the amount of water leaving the main channel and flowing onto the floodplain and proposed a numerical method for a steady flow scenario. Of particular interest to the research being conducted in Ohio is the contribution of overbank flooding to water quality improvement and how to quantify that impact. Prior to addressing this water quality issue, knowledge regarding the flooding characteristics and the current state of the stream are required to determine if out-of-bank discharges are likely to have a significant impact on water quality in this system. A hydrologic study of agricultural ditches containing low benches indicated that the benches were flooded between 10 and 60 days annually (Kallio et al. 2010). These flooding events were associated with discharges equivalent to $30 \%$ of the 2 -year discharge (Kallio et al. 2010). Additionally, simulation studies suggest that nitrate-N removal may be as great as $20 \%$ if the floodplain area is equivalent to at least $1 \%$ of the watershed area (Kallio et al. 2010).

In water quality studies, increasing attention has focused on the impacts of stream stability and bank erosion and resulting sediment loads. Dynamic equilibrium is achieved when a stream consistently transports its sediment load, allowing neither aggradation nor degradation (Rosgen 1994). Dynamic equilibrium is often related to a channel-forming discharge that is known as bankfull discharge if it is based on measurements of the channel geometry. If the channel-forming discharge is based on sediment transport, it is referred to as effective discharge (Powell et al. 2006).

The bankfull elevation can be determined by making measurements of fluvial features in a stream system. Bankfull discharge is then calculated with a resistance equation, such as the Manning's equation (Ward and Trimble 2004), and measured cross-section and slope data. On wadeable streams, this approach is commonly used rather than determining the effective discharge. This approach is associated with much uncertainty-particularly in entrenched systems. Often, the bank-

Beth E. Fry is an engineer at AECOM Water in Kansas City, Missouri. Andy Ward is a professor in the Department of Food, Agricultural, and Biological Engineering at The Ohio State University in Columbus, Ohio, and Kevin W. King is a research agricultural engineer with the USDA Agricultural Research Service Soil Drainage Research Unit in Columbus, Ohio. 
full or effective discharge is associated with a recurrence interval, such as the 1.5-year recurrence interval (Leopold 1994; Simon et al. 2004). However, Powell et al. (2006) found the range to be from 0.3 to $1.4 \mathrm{y}$ in a study of large rivers in Ohio. Researchers have also noted that the recurrence interval is much less for small headwater systems (Ward et al. 2004; Jayakaran et al. 2005). Determining the recurrence interval of the channel-forming discharge should provide useful insight, or confidence, on this discharge and whether the channel is entrenched or in a state of dynamic equilibrium (Powell et al. 2006).

Frequent floods that exceed the bankfull discharge are also important to the structure of biological habitat (Junk et al. 1989; Power et al.1995; Robertson et al. 2001; Bowen et al. 2003), and the chemical water quality (Pinay et al. 2002). The frequency of low magnitude floods has been linked to the habitat dynamics of a stream system, but measuring these impacts is often difficult because of their short duration and unpredictable nature. To study the impact of flood frequency on tree production, Robertson et al. (2001) produced artificial flood events, representing seasonal floods. Others have taken a modeling approach to describe the frequency of flooding and the availability of shallow water habitat over time (Bowen et al. 2003).

Estimates of the recurrence interval of the bankfull discharge for a large river can be related to geomorphology measurements, hydraulic calculations, and historic records of discharges at a nearby streamflow gage (Powell et al. 2006). Quantifying the flood characteristics of small, ungaged streams is more complicated than with large rivers because of the lack of long periods of recorded stream flow data (Poff et al. 1997). Regional flood frequency methods have been developed to transfer data from gaged to ungaged sites, and the two most commonly used approaches are statistically fitting regression equations to measured data and the index-flood method (Haan 2002). Regression equations for ungaged, rural watersheds have been developed for Ohio based on basin characteristics and frequency estimates of 305 streamflow gages (Koltun 2003). Another common method is the index flood method, where it is assumed that two homogenous regions have the same frequency distribution, apart from scale (Sveinsson et al. 2003). Other methods have also been considered, such as the use of rainfall-runoff simulation models to

\section{Figure 1}

Location of the Sugar Creek Watershed in relation to the Upper Big Walnut Creek Watershed and Ohio counties. A streamflow gage is located at the outlet.

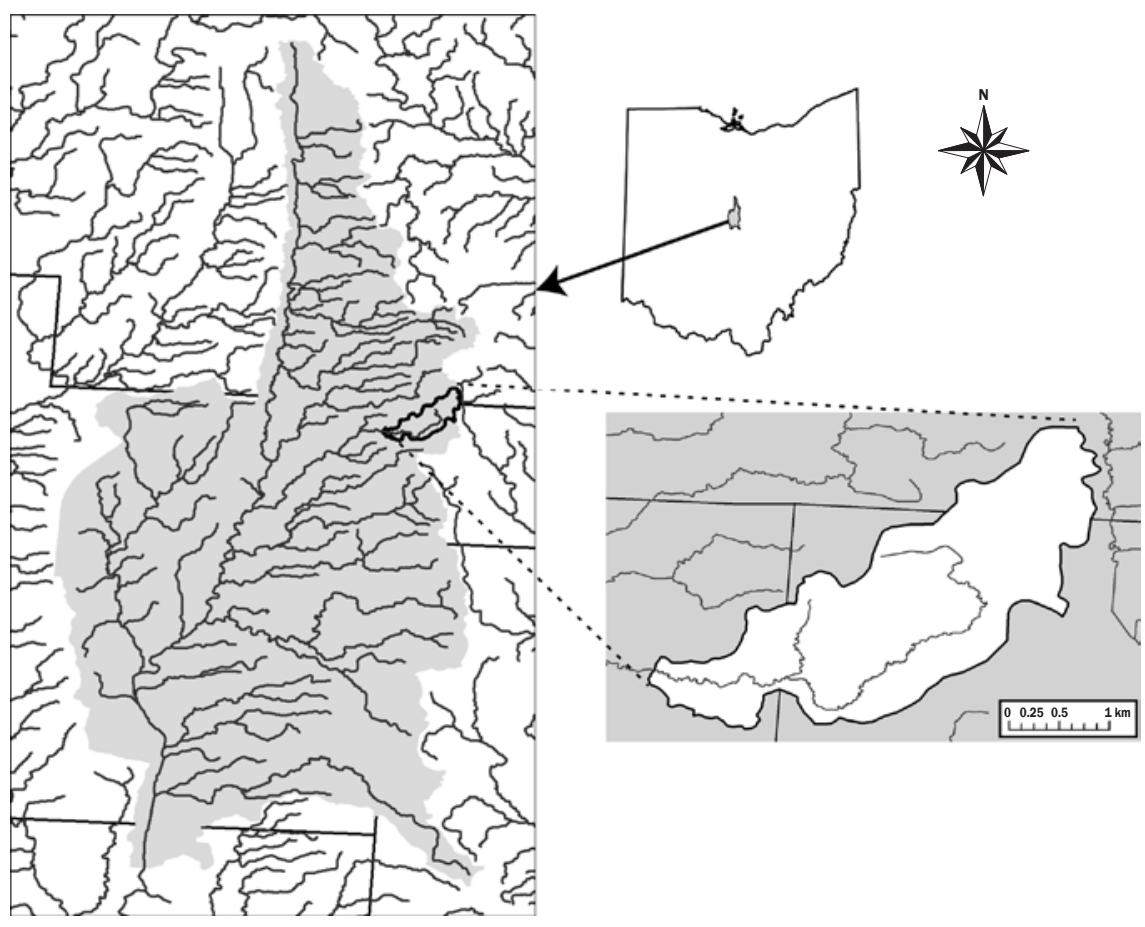

relate the frequency of rainfall events to the generated peak discharge or runoff volume. This method performed best with extreme rainfall events (Bradley and Potter 1992). Common methods for estimating recurrence interval discharges are applied at the outlet of the watershed, and the bankfull discharge is assumed to be consistent along the system. However, compared to larger rivers, smaller stream systems are more influenced by the surrounding landscape and have more variability in the geomorphology and, therefore, in the frequency of bankfull discharge (Leopold 1994).

Quantifying the frequency and magnitude of out-of-bank flows is critical for understanding headwater hydrology. The objective of this study was to determine the frequency and magnitude of channel-forming discharges in Sugar Creek, a tributary to Upper Big Walnut Creek Watershed, Ohio.

\section{Materials and Methods}

Site Description. The Upper Big Walnut Creek Watershed has a $492 \mathrm{~km}^{2}\left(190 \mathrm{mi}^{2}\right)$ drainage area and is located in Delaware, Franklin, Morrow, Licking, and Knox counties. It drains into the Hoover Reservoir, which serves as a water source for approxi- mately 800,000 residents in the Columbus area. The primary land use throughout the watershed is crop production agriculture, the soil is classified as predominately hydrologic soil group $\mathrm{C}$, and a portion of the land has subsurface drainage. The average annual precipitation is $985 \mathrm{~mm}$ (38.8 in). Sugar Creek (figure 1) is a tributary of Upper Big Walnut Creek and has a drainage area of $4.1 \mathrm{~km}^{2}(1.6$ $\mathrm{mi}^{2}$ ). A study of orthophotos from 1939 to the present show almost no changes in land uses in the watershed.

Soils in the watershed are primarily of silt loam texture, which include Amanda (7\%), Bennington (32\%), and Centerburg (37\%), and are classified as hydrologic soil group C. The remaining soils are a silty clay loam Pewamo (11\%), which is a hydrologic soil C/ $\mathrm{D}$. The main land uses are crop production agriculture (65\%), woods (33\%), and small wetlands (1\%).

The USDA ARS have established a streamflow monitoring station at the outlet of Sugar Creek. The monitoring station was instrumented with a $2.4 \mathrm{~m}$ (8 ft) Parshall flume and an Isco 4230 bubbler for recording stage. Stage was recorded on 10-minute intervals. Flume submergence or tailwater was a frequent occurrence because of the 
low gradient within the study stream. Thus, an ISCO 2150 area velocity sensor was positioned in the center of flow at the throat of the flume to measure mean velocities during the submergence periods. Discharge was calculated by developing a stage discharge relationship using the stage and velocity measurements. Precipitation was measured with Isco 674 tipping bucket rain gages located adjacent to the flumes and recorded simultaneously with stage.

The United States Geological Survey (USGS) has a stream gage (USGS Gage 03228300) located on Big Walnut Creek at Sunbury. Data for the gage were obtained from the USGS National Water Information System database website (http://nwis.waterdata.usgs.gov/nwis). This included 14 years of annual peak discharges and 16 years of daily mean discharges.

Stream Geomorphology Measurement and Analysis. A reconnaissance was performed by walking the entire length of Sugar Creek. Potential sites for obtaining geomorphology information were identified and then marked on aerial photographs. Criteria for site selections were that they had to be physically

\section{Figure 2}

Aerial photograph of the Sugar Creek Watershed showing the locations of the eight measured reaches, labeled by the stream kilometer (S.K.) and tributary (T) distance from the outlet gage.

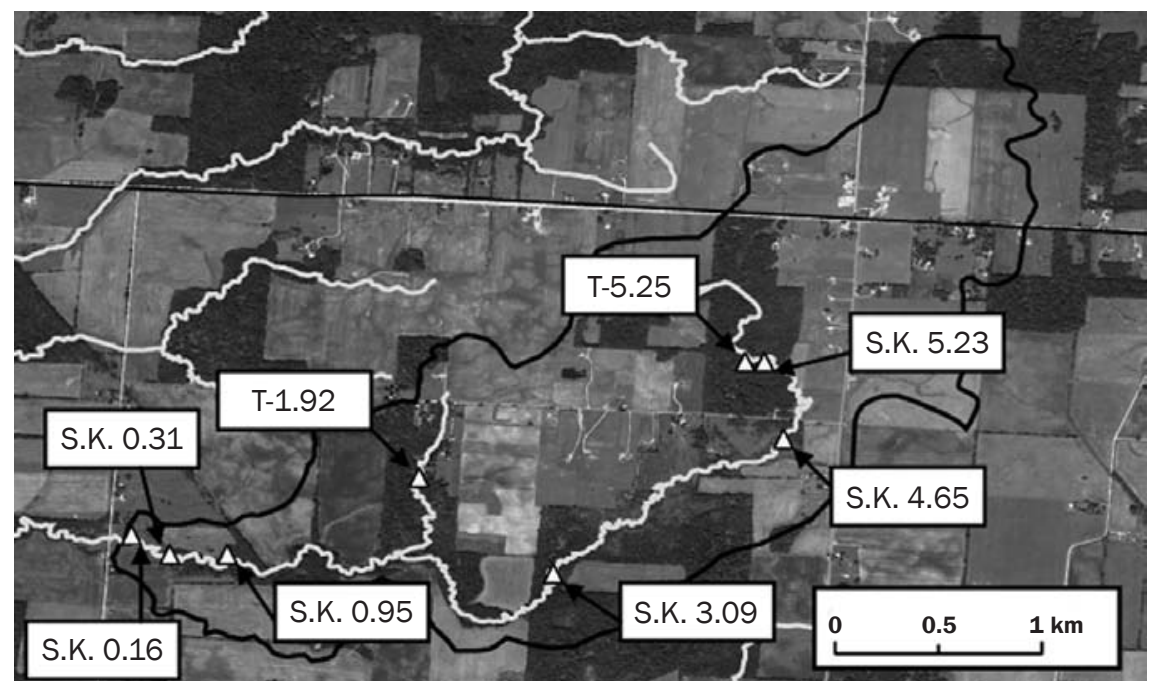

accessible and that the land owner approved access to the property. Eight sites were chosen for detailed reach surveys (figure 2) - six along the main stem and two along tributaries. Sites are identified by their distance upstream from the gage at the outlet. Images and descriptions of typical sites are shown in figure 3 .

Procedures for surveying the stream were adopted from those presented by Harrelson

\section{Figure 3}

(a) Site 0.16 was located in a densely vegetated floodplain and had stable channel dimensions. (b) Site 0.31 was located in a meadow landscape with a densely vegetated floodplain and had small channel dimensions that were determined to be in equilibrium. (c) Site 0.95 was located in a wooded area with tall grasses on the floodplain. (d) Site 3.09 was located in a wooded area with an agricultural field on the left bank and an active floodplain on the right bank. (e) Site 4.65 , located near Porter Lane, was slightly entrenched with fluvial features building within the channel. (f) Site $\mathbf{5 . 2 3}$ was located near the top of the stream.

(a)

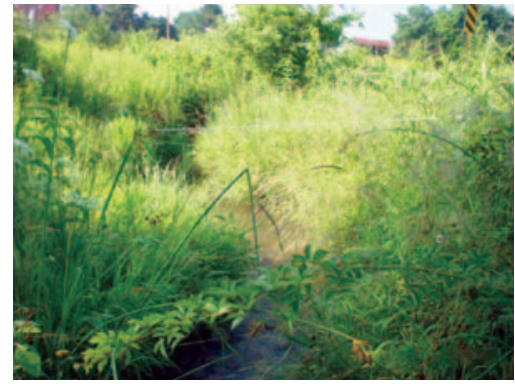

(d)

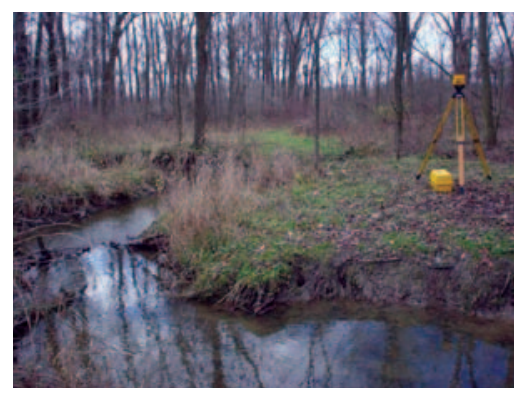

(b)

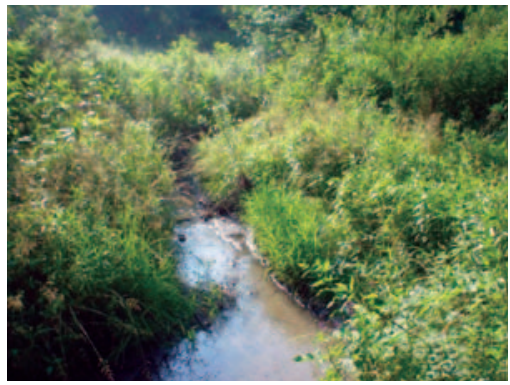

(e)

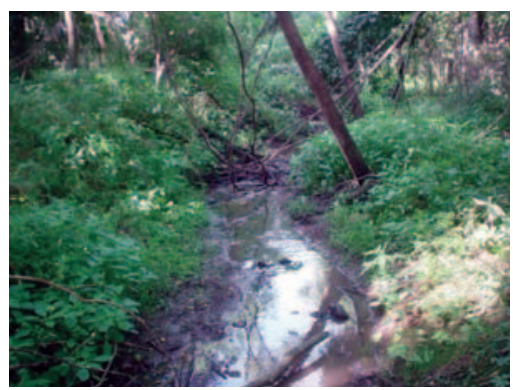

(c)

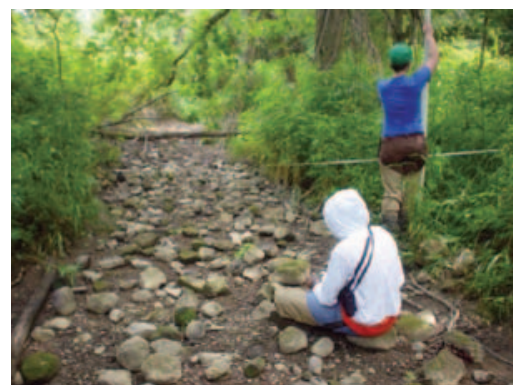

(f)

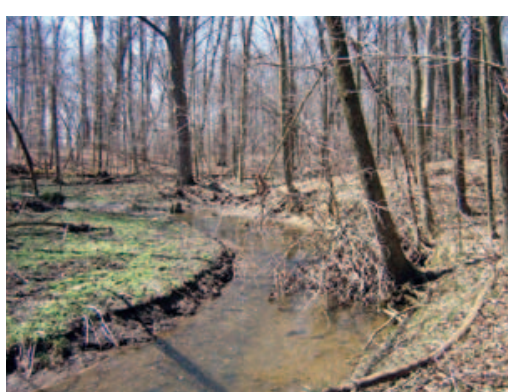


et al. (1994) and Ward and Trimble (2004). Surveys were conducted to gain information on the longitudinal profile, pattern, bed materials, and cross-section dimensions. Measurements made at incremental distances within the channel included the bed elevation; water depth, or the water surface profile; azimuth readings parallel to the banks; bankfull elevations on either bank when a bankfull feature was identified; and the particle size measurements of the bed material in riffles.

The geomorphology data were used to determine if the stream was in dynamic equilibrium, unstable, or in a state of transition by (1) comparing the dimensions of Sugar Creek to bankfull dimensions predicted by preexisting regional curves, (2) relating the bed materials to the theoretical particle at incipient motion due to the shear stress associated with the bankfull discharge, and (3) determining if the recurrence interval of the bankfull discharge was similar to the expected recurrence interval.

The data collected from the stream surveys were entered into The Reference Reach Spreadsheet version 4.01L (Mecklenburg and Ward 2004) of the Spreadsheet Tools for River Evaluation, Assessment and Monitoring (STREAM), which aid in determining bankfull attributes and provide a graphical plot of the profile, pattern, dimensions, and particle distribution. The mean shear stress, or tractive force, for each reach was calculated as

$T=1000 d s$,

where $T$ is the tractive force $\left(\mathrm{kg}\right.$ force $\mathrm{m}^{-2}$ ), $\mathrm{d}$ is the depth of flow $(\mathrm{m}), \mathrm{s}$ is the slope of the water surface, as a fraction, and $1000 \mathrm{~kg}$ $\mathrm{m}^{-3}$ is the specific weight of water. The mean particle size that can be moved by the tractive force at bankfull depth was

$d_{50}=c T$,

where $d_{50}$ is the mean particle at incipient motion, or threshold particle $(\mathrm{cm}), T$ is the tractive force, and $c$ is $1 \mathrm{~cm} \mathrm{~kg}^{-1} \mathrm{~m}^{-2}$, when $\mathrm{T}$ is equal to or greater than $1 \mathrm{~kg} \mathrm{~m}^{-2}$. The threshold particle size was compared to the measured particle sizes $\left(d_{50}\right.$ and $\left.d_{84}\right)$ to determine if the stream was able to move the measured bed materials, or if it was aggrading or eroding.

The drainage areas for each location were determined using an electronic planimeter and a USGS 7.5 minute topographic map. The bankfull dimensions (width, area, and mean depth) were plotted on the regional curve for the Upper Scioto River Watershed. The Upper Big Walnut Creek is a tributary of the Scioto River.

Discharge Frequency Analysis. A frequency analysis was performed on annual peak discharges using the Weibull method (Ward and Trimble 2004) for calculating discharges for the 2-, 5-, 10-, and 25-year recurrence interval events. A method by Mockus (1960) was used to establish that available periods of record were of adequate length to determine discharge versus recurrence interval relationships with a $90 \%$ probability of occurrence.

The frequencies associated with recurrence interval discharges, in times per year, were estimated with a time duration analysis of the daily discharges measured at the USGS gage. Quantifying the average annual volume of overbank flows, as a percentage of the total flow, utilized a combination of the generated flow hydrographs and the frequencies associated with recurrence interval discharges. In addition to projecting the more frequent discharges, the STREAM Module: Contrasting Channels version 4.0 (Mecklenburg and Ward 2004) uses the USGS rural equations to provide discharge versus recurrence interval estimates (Koltun 2003).

To determine the discharge recurrence interval relationship at Sugar Creek, an analysis of the following three methods for estimating recurrence interval discharges of ungaged streams was conducted: (1) using the uncalibrated USGS rural equation, (2) calibrating the USGS rural equation using measured data at the USGS Sunbury gage, and (3) generating peak discharges with the Hydrologic Engineering Center's Hydrologic Modeling System (HEC-HMS). The third method used HEC-HMS rainfall-runoff simulations to relate the recurrence interval of 24-hour hypothetical storm events to the peak discharge generated at the outlet. Rainfall depths with 2-, 5-, 10-, 25-, 50-, and 100-year recurrence intervals were obtained from Ward and Trimble (2004). The assumption with this approach is that the simulated peak discharges have the same probability as the hypothetical storm event (Bradley and Potter 1992).

Modeling Approach. The US Army Corps of Engineers Hydrologic Engineering Center's Hydrologic Modeling System (HEC-HMS) (Scharffenberg and Fleming
2005) was used to simulate the rainfallrunoff interactions of the watershed and to produce hydrographs as input for the River Analysis System (HEC-RAS). HEC-RAS (Version 3.1.3) generated stage and flow hydrographs, which were used to develop discharge recurrence interval relationships for selected locations along Sugar Creek. Though both HEC models are river routing models, HEC-RAS was used because it creates stage-discharge relationships for all of the cross sections of a reach, providing more insight on the occurrence of bankfull discharge than using only HEC-HMS. Natural channel flow is almost always unsteady and nonuniform, meaning the dependent flow variables, depth and discharge, are functions of distance and time. The equation solver in HEC-RAS for unsteady flow was adapted from the UNET model, developed by Barkau (1993). It was primarily developed for subcritical flow regime calculations (Brunner 2002). The unsteady flow equations are applied to floodplain flow in one dimension, ignoring the exchange of momentum between the channel and the floodplain. Therefore, the overbank floodplain areas are treated as a separate channel flowing normal to the direction of flow in the main channel.

Parameterization of the Hydrologic Engineering Center's Hydrologic Modeling System. The hydrologic modeling system, HEC-HMS (Scharffenberg and Fleming 2005) simulates the rainfall-runoff processes of watersheds with the following series of elements that represent the watershed and river system: subbasins, reaches, junctions, reservoirs, diversions, sources, and sinks. The hydrographs produced for each subbasin were the primary interest for this study, so the following discussion focuses on the runoff processes. Twelve drainage areas, or subbasins, were delineated and arranged to represent the Sugar Creek Watershed. Each subbasin was connected to a point on a reach element where representative cross-section data had been measured (figure 4).

Curve numbers were calculated for each of the subbasins delineated for the Sugar Creek Watershed. The land use descriptions for Sugar Creek were obtained from aerial photos and a field reconnaissance. To account for multiple land uses in the watershed, an area-weighted curve number was calculated for each of the subbasins.

For model accuracy, Scharffenberg (2001) recommended that the simulation time inter- 


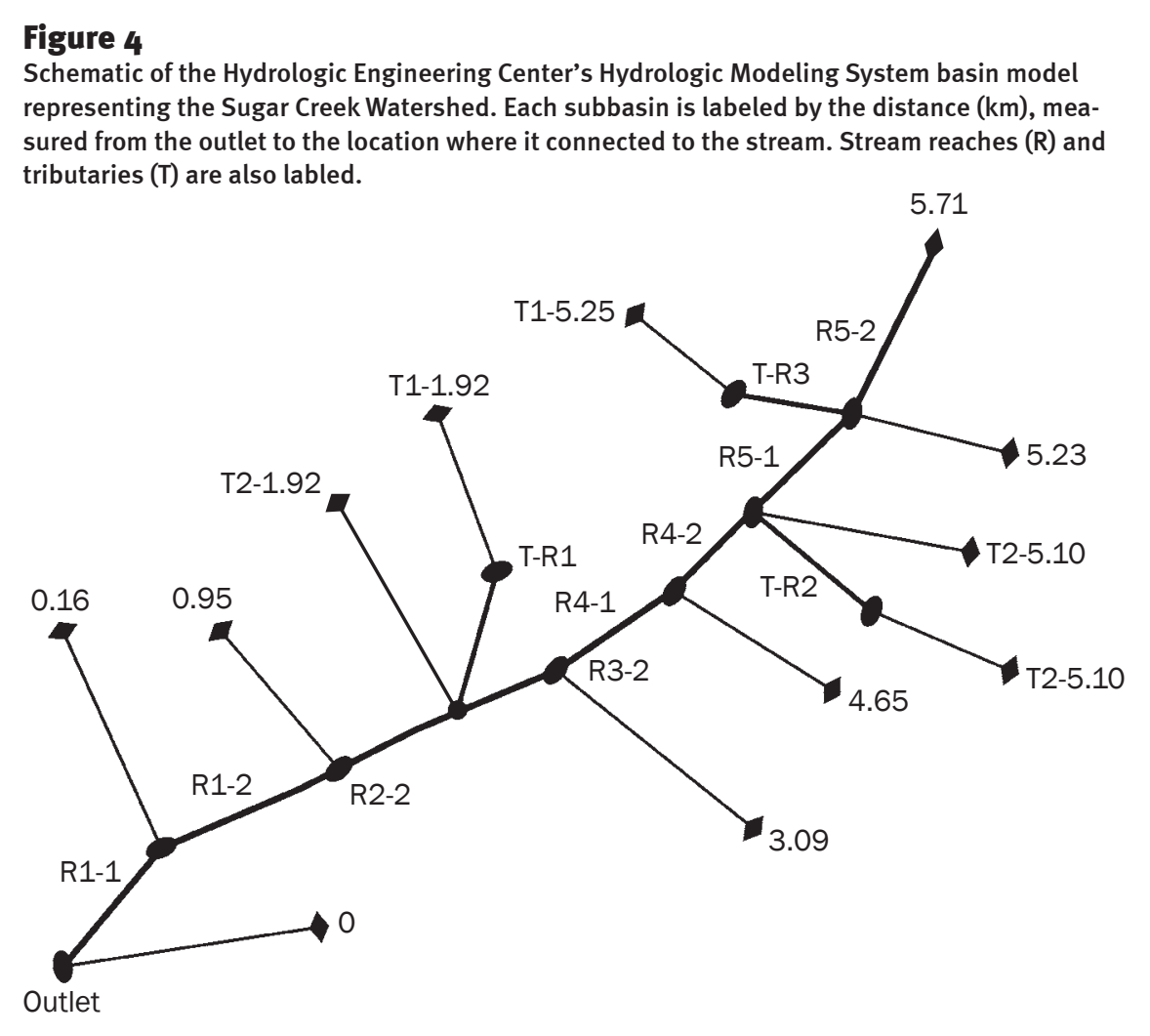

val be less than 0.29 times the lag time of each subbasin. Calculated lag times ranged from 16 to 66 minutes, so a 5 minute computation interval was used for all of the subbasins and all simulations. A constant monthly baseflow was entered for each subbasin, primarily because it was required for the stability of the HEC-RAS model. Discharge data measured at baseflow conditions were available from May 6, 2005 through September 28, 2005, ranging from 0 to $0.04 \mathrm{~m}^{3} \mathrm{~s}^{-1}\left(1.4 \mathrm{ft}^{3} \mathrm{sec}^{-1}\right)$. The average discharge measured at baseflow conditions, $0.02 \mathrm{~m}^{3} \mathrm{~s}^{-1}\left(0.7 \mathrm{ft}^{3} \mathrm{sec}^{-1}\right)$, was selected as the discharge for the outlet. Baseflow for each subbasin was estimated as the total baseflow multiplied by the fraction of the total area associated with a subbasin.

In addition to simulating rainfall-runoff processes of the watershed, HEC-HMS also routes the runoff through a stream channel. The Muskingum-Cunge 8-Point Section approach was used to account for any storage or reduction in the peak discharges resulting from overbank flow (Feldman 2000). Measured cross-section data from the field survey were approximated as geometric shapes, ensuring that the area of the channel and the width of the floodplain were maintained. Each cross section represented the length of a representative reach, and the slope of each reach was the average slope measured during the reach survey. Manning's $n$ roughness coefficients were required for each channel and overbank area. The $n$ values for the channel, were obtained from the Reference Reach spreadsheet, which provided values based on bankfull depths and measured material sizes. The values for the floodplains were obtained based on descriptions from observations made in the field (example photographs provided in Arcement and Schneider [1989]) and then selecting values from table 7.1 in Ward and Trimble (2004).

Simulated peak discharges and runoff volumes were compared to 33 observed sets of values measured in 2005 at the outlet by the USDA-ARS. The 33 observed runoff events were analyzed to determine the 5-day antecedent precipitation, and each event was lated with the appropriate basin model.

Parameterization of the Hydrologic Engineering Center's River Analysis System. The steps taken to use the HEC-RAS model were based on guidelines and recommendations in the HEC-RAS User's Manual (Brunner 2002) and Dyhouse et al. (2003). The combination of data collected during the geomorphology field survey and parameters used in HEC-HMS fulfilled most of assigned an AMC I, II, or III and then simu- the requirements of the Geometric Data editor. Additional data requirements included the downstream reach lengths for the channel and the banks and the contraction and expansion coefficients. The contraction and expansion coefficients were left as the default value for each cross section, which were 0.1 and 0.3 , respectively, as they are the values that represent natural streams. Additional cross sections were added to the Geometry Data Editor with the XS-Interpolation tool with a maximum spacing of $90 \mathrm{~m}(295 \mathrm{ft})$.

Important parameters in the computation of unsteady flow include boundary conditions, cross-section spacing, and a computational time step. The results of the computations include plots of cross sections with water surface elevations for each time step, water surface profiles for each time step, rating curves for each cross section, stage and flow hydrographs for each cross section, and tabular output of the rating curves and hydrographs. The hydrographs representing the total outflow from the tributaries entering the main stem were input as lateral inflows. The computation time step, according to Brunner (2002), is the most important parameter for unsteady flow analysis. A time step of 1 minute was used in the analyses.

Flooding Analysis. The Hydrologic Engineering Center's Hydrologic Modeling System (HEC-HMS) was used to generate hydrographs that were entered into HEC-RAS, which then computed unsteady flow conditions within the stream channel. Rainfall events, beginning with the smallest depth that generated runoff in the HECHMS watershed and increasing at intervals of $5 \mathrm{~mm}$ (0.2 in), were simulated, and the runoff hydrographs from each subbasin were input and simulated in HEC-RAS.

To determine the times per year that the bankfull discharge recurrence intervals for Sugar Creek were exceeded, a duration analysis to determine the probability of exceedence of the daily discharges at the Sunbury gage was completed. The first step in the process was to sort the entire dataset of daily discharges in descending order and then rank them. Each rank was divided by the total number of days in the record to provide a percentage of time each flow was met or exceeded. The recurrence intervals associated with bankfull discharges for Sugar Creek were applied to the discharge recurrence interval relationship developed for the Sunbury gage to determine the correspond- 
ing daily discharge, which will be called the "bankfull-daily discharge." The sorted daily discharges were divided by the bankfull-daily discharges, which calculated a discharge ratio. The percentage associated with a discharge ratio of 1 represented the times per year that bankfull-daily discharge was exceeded, which also represented the times per year the bankfull discharge at Sugar Creek was exceeded.

Magnitude of Overbank Flooding. The time duration analysis discussed in the previous section was also used to estimate the discharge ratios and the exceedence probabilities for each of the peak discharges generated in HEC-RAS with the $5 \mathrm{~mm}$ (0.2 in) incremental rainfall-runoff events. Knowledge of the average number of days per year each discharge occurred was used in the calculation of the average annual volume of overbank flow. The volumes were estimated as the total area under the hydrograph or the area between the peak of the hydrograph and bankfull discharge. After the volumes and durations of each recurrence interval discharge were calculated, the average annual volume of flow could be estimated:

$\sum\left[\left(\frac{V_{R I-1}+V_{R I}}{2}\right)\left(d_{R I-1}-d_{R I}\right)\right]$,

where $V_{R I}$ is the volume of flow for a specific recurrence; $V_{R I-1}$ is the volume of a preceding simulation, with a more frequent recurrence interval; and $d$ is the frequency of occurrence, in days per year. Equation 3 was applied to the total volumes and the volume overbank. The average annual overbank volume was divided by the total volume, representing the annual percentage of overbank volume for the overbank flows at Sugar Creek.

\section{Results and Discussion}

Stream Geomorphology. The measured bankfull dimensions at the 8 sites and regional curves for the Upper Scioto River are presented in figure 5. Much of the scatter is because three stream types were present at Sugar Creek (table 1). All sites, except site 4.65, were classified as stable Rosgen Type E or $\mathrm{C}$ streams. Several of the sites had characteristics of meadow streams (Rosgen Type E) with width to depth ratios of 12 to 15 , while other sites had more distinct riffles and pools (Rosgen Type C) with width to depth ratios of 22 to 24 . All the stable sites had a sinuosity of 1.3 to 2.1. Site 4.65 had a sinuosity of 1 , was incised, and had ditch/gully characteristics.

\section{Figure 5}

Measured bankfull dimensions and the corresponding regional curves for the Upper Scioto River regional curve (solid regression lines) (Witter 2006).

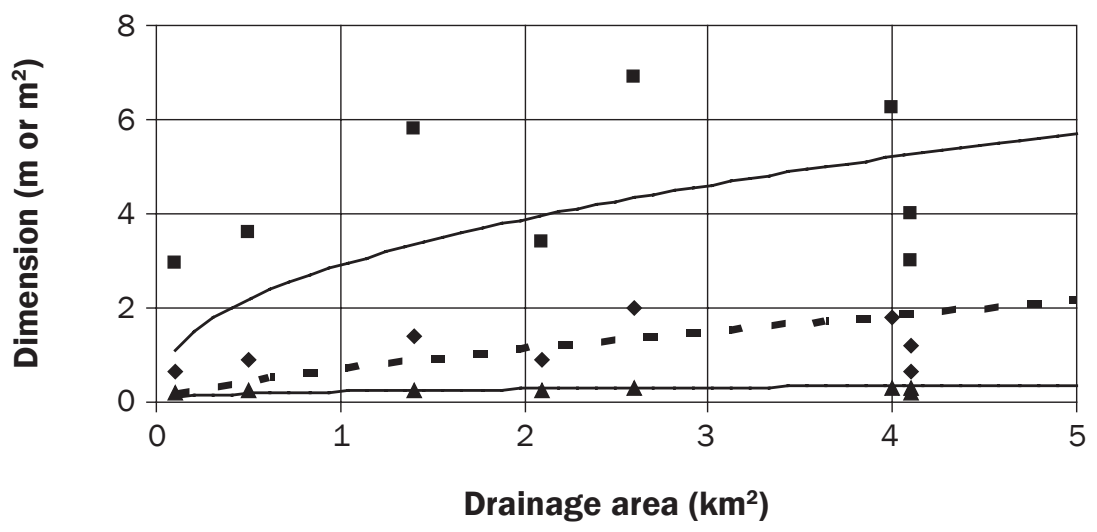

Legend

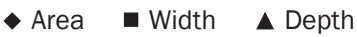

\section{Table 1}

Bedslope, bankfull depth, measured particle size $\left(d_{50}\right.$ and $\left.d_{84}\right)$ of the bed material, and the calculated threshold at motion (threshold $d_{50}$ ) for six reaches on the main stem and two tributaries of Sugar Creek.

\begin{tabular}{llllllllc}
\hline Subbasin & $\begin{array}{l}\text { Drainage } \\
\text { area }\left(\mathbf{k m}^{2}\right)\end{array}$ & $\begin{array}{l}\text { Rosgen } \\
\text { class }\end{array}$ & ER & $\begin{array}{l}\text { Depth } \\
(\mathbf{m})\end{array}$ & $\begin{array}{l}\text { Bedslope } \\
(\mathbf{\%})\end{array}$ & $\begin{array}{l}\boldsymbol{d}_{\mathbf{5 0}} \\
(\mathbf{m m})\end{array}$ & $\begin{array}{l}\boldsymbol{d}_{\mathbf{8}} \\
(\mathbf{m m})\end{array}$ & $\begin{array}{l}\text { Threshold } \\
\boldsymbol{d}_{\mathbf{5 0}}(\mathbf{m m})\end{array}$ \\
\hline 0.16 & 4.1 & E4-C4 & 18 & 0.21 & 0.26 & 4.0 & 46 & 5 \\
0.31 & 4.1 & E6-C6 & 14 & 0.30 & 0.29 & 0.1 & 6 & 7 \\
0.95 & 4.0 & C4 & 15 & 0.28 & 0.32 & 24.0 & 76 & 10 \\
T-1.92 & 0.5 & E4-C4 & 8 & 0.24 & 0.72 & 31.0 & 64 & 18 \\
3.09 & 2.6 & C4 & 10 & 0.29 & 0.16 & 0.1 & 29 & 5 \\
4.65 & 2.1 & E4-G4 & 2 & 0.26 & 0.69 & 3.0 & 16 & 20 \\
5.23 & 1.4 & C6 & 5 & 0.24 & 0.23 & 0.1 & 6 & 5 \\
T-5.25 & 0.1 & E6-C6 & 4 & 0.22 & 0.48 & 0.1 & 7 & 9 \\
\hline
\end{tabular}

Note: $\mathrm{ER}=$ entrenchment ratio.

The results in table 2 show that for many of the reaches, the majority of the dimension estimates were within $\pm 50 \%$ of the regional curves estimates. The biggest differences were at site 0.16 near the outlet and tributary T-5.25 in the headwaters. Site 0.16 had a very broad active floodplain and one of the smallest bankfull channels. Dimensions for tributary T-5.25 were much larger than would be expected. The results for site 4.65 suggest good agreement, but like many modified ditch systems, the bankfull feature at this location was a small bench.

Site 3.09, an example with good stream geomorphology attributes, had a sinuosity of 1.6 and a broad active floodplain located at the bankfull elevation (figure 6). In contrast, site 4.65 , with the poorest stream geomorphology attributes, had a straight channel, only a grade break at the bankfull elevation, and a sloping narrow floodplain.

The mean particle size at the threshold of motion for five of the eight sites was between the measured $d_{50}$ and $d_{84}$ sizes, or slightly larger than the $d_{84}$ (table 1 ). At site 4.65 , the calculated shear stresses were large enough to move particles greater than the measured $d_{84}$ bed material. This suggests the potential for scour at that location.

Flooding Analysis. The fitted discharge versus recurrence interval relationship for the annual peak discharge series recorded at Big Walnut Creek at Sunbury (USGS Gage 03228300) had a coefficient of determination $\left(r^{2}\right)$ of 0.88 and is

$Q=49.3 \operatorname{Ln}(R I)+71.3$ 
Table 2

Comparison of measured bankfull dimensions and dimensions predicted by the Upper Scioto Regional Curve.

\begin{tabular}{|c|c|c|c|c|c|c|c|c|}
\hline \multirow[b]{2}{*}{ Subbasin } & \multirow{2}{*}{$\begin{array}{l}\text { Drainage } \\
\text { area }\left(\mathbf{k m}^{2}\right)\end{array}$} & \multirow{2}{*}{$\begin{array}{l}\text { Cross section } \\
\text { number }\end{array}$} & \multicolumn{2}{|c|}{ Bankfull area $\left(\mathbf{m}^{2}\right)$} & \multicolumn{2}{|c|}{ Bankfull width (m) } & \multicolumn{2}{|c|}{ Bankfull depth (m) } \\
\hline & & & Measured & Predicted & Measured & Predicted & Measured & Predicted \\
\hline 0.16 & 4.1 & 3 & 0.65 & 1.85 & 2.98 & 6.50 & 0.22 & 0.50 \\
\hline 0.31 & 4.1 & 2 & 1.10 & 1.85 & 4.1 & 6.50 & 0.30 & 0.50 \\
\hline 0.95 & 4.0 & 3 & 1.95 & 3.30 & 6.68 & 6.40 & 0.29 & 0.50 \\
\hline T-1.92 & 0.5 & 3 & 1.08 & 0.90 & 3.89 & 3.10 & 0.28 & 0.30 \\
\hline 3.09 & 2.6 & 3 & 2.00 & 1.30 & 6.88 & 4.40 & 0.29 & 0.30 \\
\hline $\mathrm{T}-5.25$ & 0.1 & 3 & 0.64 & 0.13 & 2.96 & 1.15 & 0.22 & 0.11 \\
\hline Mean & & & 1.27 & 1.41 & 4.67 & 4.43 & 0.27 & 0.35 \\
\hline
\end{tabular}

where $Q$ is the discharge $(\mathrm{cm})$ and $R I$ is the recurrence interval in years. The relationship for daily discharge series at the same gage had a coefficient of determination $\left(r^{2}\right)$ of 0.92 and is
$Q=29.3 \operatorname{Ln}(R I)+48.1$.

The recurrence interval discharges for the USGS gage and discharges estimated with methods 1 through 3 are provided in table

\section{Figure 6}

The first measured cross sections for (a) site 3.09 and (b) site 4.65. The bankfull elevation is at the dashed line.

(a)

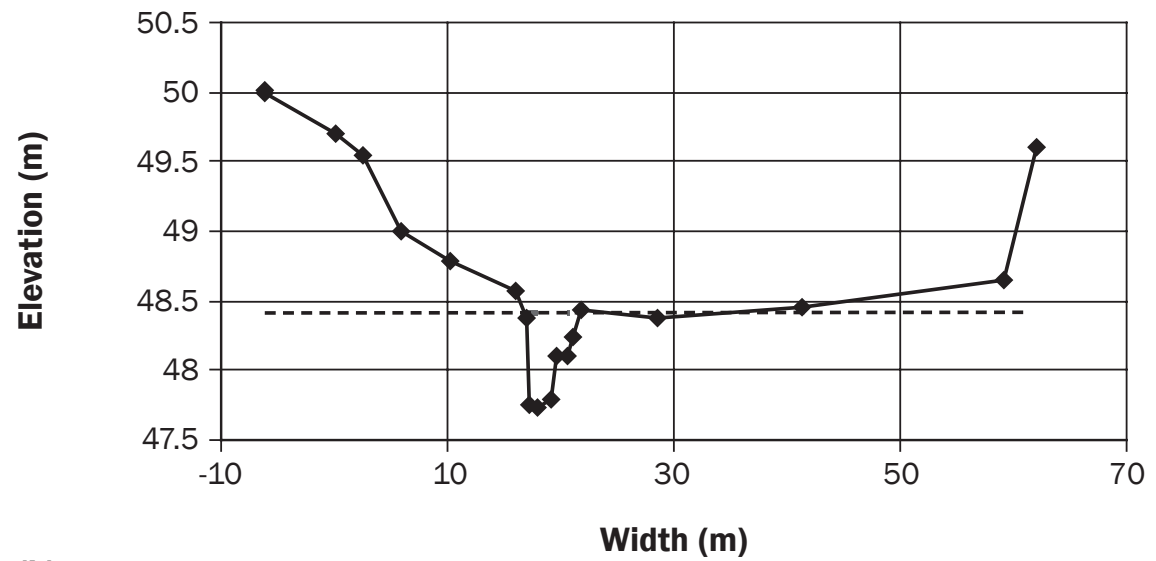

(b)

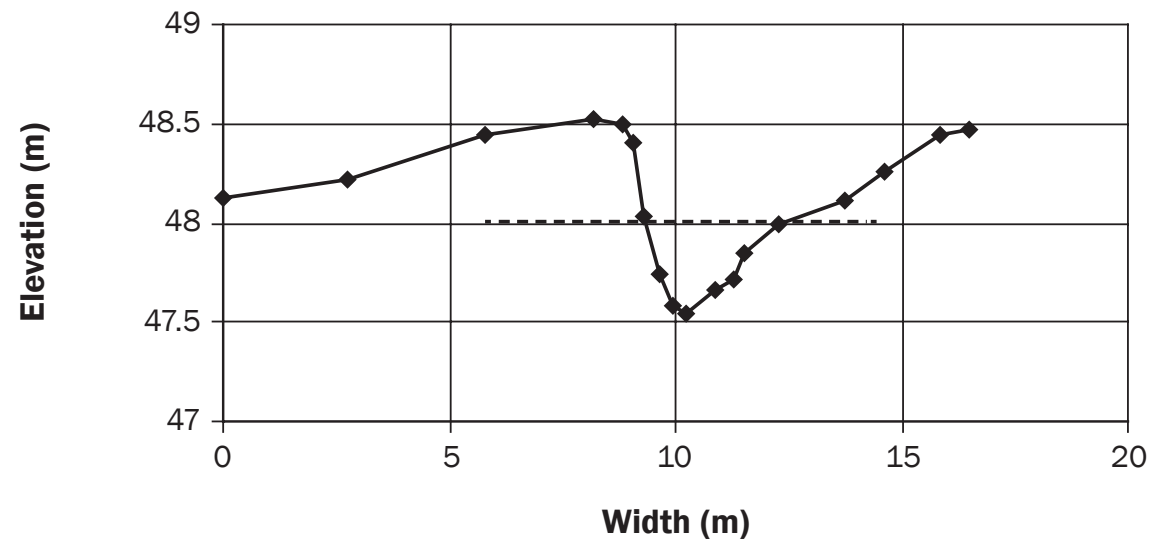

3, together with calibration ratios (measured annual peaks divided by the USGS equationpredicted values).

A time duration analysis was conducted on the recurrence intervals associated with bankfull discharge, producing a graph, as in figure 7 , for each location. The arrow in figure 7 illustrates where the ratio of the daily mean discharge and the bankfull discharge equals one and the corresponding probability of exceedence.

The predicted and measured peak discharges and volumes of flow at the USDA ARS outlet gage for the 33 events in 2005 are presented in figure 8. Regression line attributes for a comparison between predicted and observed values are presented with the 1 to 1 line. Many of the simulated discharges had peak discharges and runoff volumes equal to zero because the basin model setup for AMC II did not produce any runoff with rainfall depths less than $25 \mathrm{~mm}$ (1 in), or in the case of event 1 , the entire rainfall hyetograph was not in the recorded data set. There was one large event simulated with AMC II, and the model predicted a discharge much larger than observed. However, the simulated volume for that large event was virtually identical to the observed volume. The HECHMS model, used to represent Sugar Creek, had a good correlation $\left(r^{2}=0.86\right)$ between the simulated and observed volumes.

The results from the HEC-RAS simulations for the outlet (site 0.16) are presented in table 4 . The calibration ratios coefficients developed from the USGS gage data (table 3) were applied to the predicted estimates to obtain the calibrated USGS values in table 4. For recurrence intervals between 0.8 to 5 years, the HEC-HMS and calibrated USGS results are similar. Bradley and Potter (1992) have stated that the runoff simulations typically perform better with more 


\section{Table 3}

Recurrence interval versus discharges for the Big Walnut Creek at Sunbury gage (USGS Gage 03228300) from the frequency analysis of the annual peak discharge data and an uncalibrated version of the US Geological Survey (USGS) Rural Peak Discharge Equation for Ohio (Koltun 2003). The calibration ratios are the ratios of the estimates based on the measured annual peaks data and the predictions with the USGS equation.

\begin{tabular}{lccl}
\hline $\begin{array}{l}\text { Recurrence } \\
\text { interval }(\mathbf{y})\end{array}$ & $\begin{array}{l}\text { Annual } \\
\text { peaks }\left(\mathbf{m}^{\mathbf{3}} \mathbf{s}^{\mathbf{1}}\right)\end{array}$ & $\begin{array}{l}\text { Predicted } \\
\text { USGS }\left(\mathbf{m}^{\mathbf{3}} \mathbf{s}^{\mathbf{1}}\right)\end{array}$ & $\begin{array}{l}\text { Calibration } \\
\text { ratio }\end{array}$ \\
\hline 0.2 & 29 & 14 & 2.0 \\
0.4 & 47 & 27 & 1.8 \\
0.8 & 70 & 44 & 1.6 \\
1.6 & 97 & 65 & 1.4 \\
2.0 & 105 & 70 & 1.5 \\
5.0 & 151 & 109 & 1.4 \\
10 & 185 & 136 & 1.4 \\
25 & 230 & 172 & 1.3
\end{tabular}

\section{Figure 7}

Ratio of daily discharges to the bankfull daily discharge against percentage of time for stream mile 3.09. This plot is used to determine the frequency of bankfull discharge. The arrow illustrates where the ratio of the daily mean discharge and the bankfull discharge equals one and the corresponding probability of exceedence.

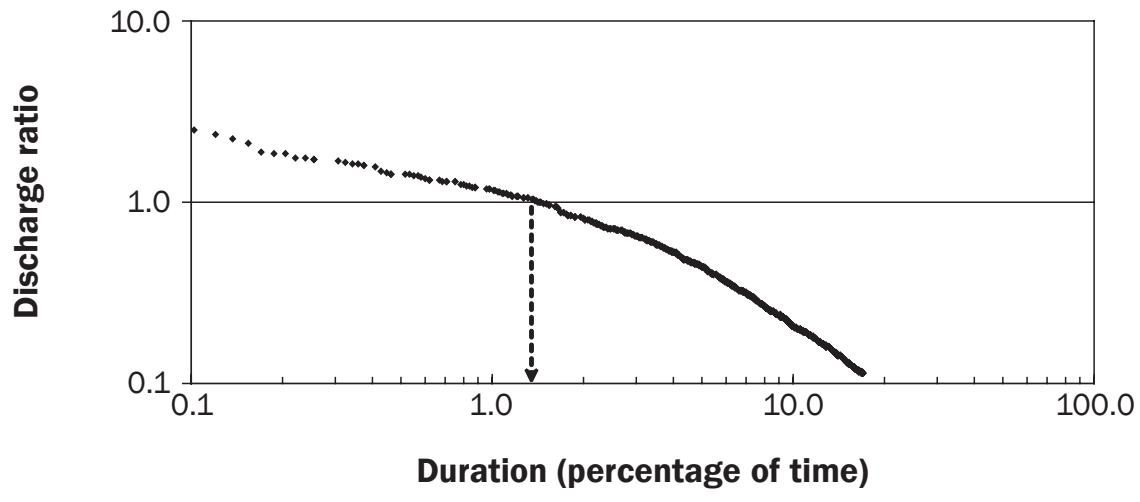

\section{Table 4}

Predicted discharges at the outlet of Sugar Creek for different recurrence intervals. The calibration ratios in table 3 were used to calibrate the uncalibrated US Geological Survey (USGS) estimates. The Hydrologic Engineering Center's Hydrologic Modeling System (HEC-HMS) results were determined from the reported rainfall depths.

\begin{tabular}{lllll}
\hline $\begin{array}{l}\text { Recurrence } \\
\text { interval }(\mathbf{y})\end{array}$ & $\begin{array}{l}\text { Rainfall } \\
\text { depth }(\mathbf{m m})\end{array}$ & $\begin{array}{l}\text { Predicted } \\
\text { USGS }\left(\mathbf{m}^{\mathbf{3}} \mathbf{s}^{\mathbf{1}}\right)\end{array}$ & $\begin{array}{l}\text { Calibrated } \\
\text { USGS }\left(\mathbf{m}^{\mathbf{3}} \mathbf{s}^{\mathbf{1}}\right)\end{array}$ & $\begin{array}{l}\text { Predicted } \\
\text { HEC-HMS }\left(\mathbf{m}^{\mathbf{3}} \mathbf{s}^{\mathbf{1}}\right)\end{array}$ \\
\hline 0.2 & 11 & 0.3 & 0.6 & 0.0 \\
0.4 & 25 & 0.7 & 1.2 & 0.2 \\
0.8 & 41 & 1.4 & 2.2 & 1.5 \\
1.6 & 58 & 2.2 & 3.1 & 3.5 \\
2.0 & 64 & 2.4 & 3.6 & 4.4 \\
5.0 & 81 & 4.0 & 5.5 & 7.4 \\
10 & 94 & 5.2 & 7.1 & 10.4 \\
25 & 104 & 6.7 & 9.0 & 12.8 \\
\hline
\end{tabular}

extreme events, but the HEC-HMS model of Sugar Creek performed well with small discharges. For this watershed, it appears that HEC-HMS underestimates small frequent discharges and overestimates discharges greater than $2 \mathrm{~cm}$ (0.79 in).

Results from the analysis of flood characteristics of Sugar Creek are presented in table 5 and show the bankfull or overbank discharge for each location; the recurrence interval associated with that discharge; the frequency, or duration, of the recurrence interval; and the annual average volume that flows overbank for each location. Among the eight locations focused on in the study, two experienced bankfull or larger discharges an average of 12 times per year, with about a 0.2 -year recurrence interval for the bankfull discharge. Seventy-five percent of the locations experienced bankfull or larger discharges an average of at least 3 times per year, with about a 0.8 -year recurrence interval. All of the locations experienced out-of-bank flows an average of at least 1 time per year, with the 2-year recurrence interval discharge. Out-of-bank flows ranged from $<1 \%$ to $13 \%$ of the average annual flow volume, with the largest volume flowing out at the furthest downstream location.

The combined results from the geomorphology analysis of Sugar Creek provided evidence of stability, or dynamic equilibrium, but also showed that one reach was entrenched. The stream was primarily characterized by two Rosgen stream types, $\mathrm{C}$ and E, which describe stable channels with welldeveloped floodplains (Ward and Trimble 2004). The bankfull cross-section measurements for the majority of sites were within $50 \%$ of the Upper Scioto River regional curve predictions of bankfull dimension, which was comparable to the measured bankfull dimensions obtained to develop the curves (Witter 2006). The regional curve and stream classification results indicate that Sugar Creek was a variable system, with different characteristics along different reaches, and was not identical to other stream channels in the region. The $\mathrm{E}$ channels in the system, and particularly at the outlet, had smaller bankfull dimensions than other locations throughout the stream. Wide, relatively flat floodplains that consisted of vegetated cohesive soils are probably the main reason for the natural establishment of sinuous $\mathrm{E}$ channels. The results of the analyses, including the threshold particle analysis, indicated 


\section{Figure 8}

A 1:1 plot of the simulated flow volumes from the Hydrologic Engineering Center's Hydrologic Modeling System basin models against (a) observed peak discharges and (b) the observed flow volumes at the gage on Sugar Creek.

(a)

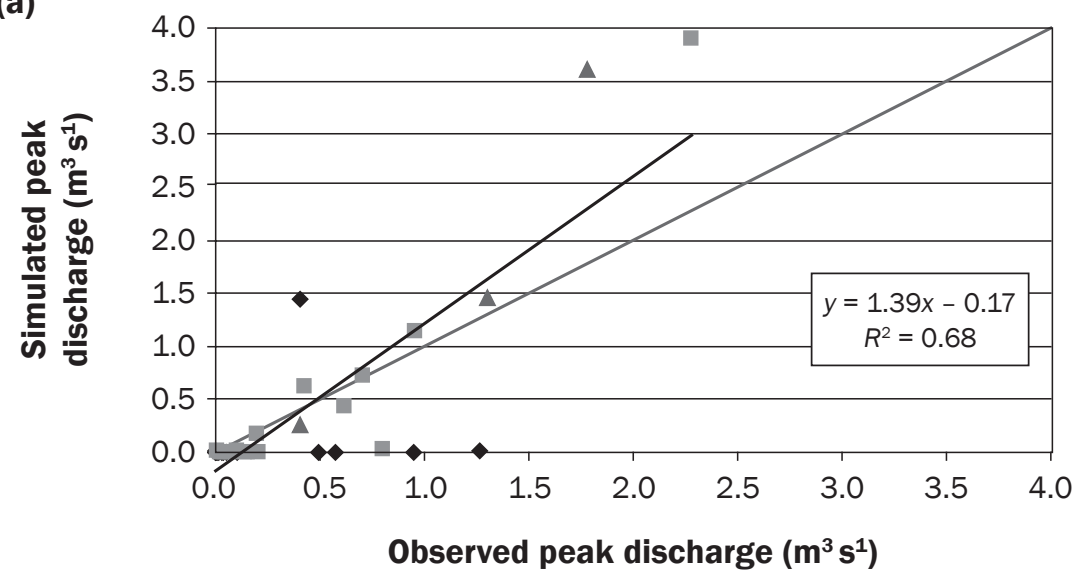

(b)

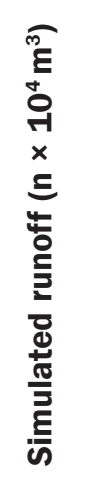

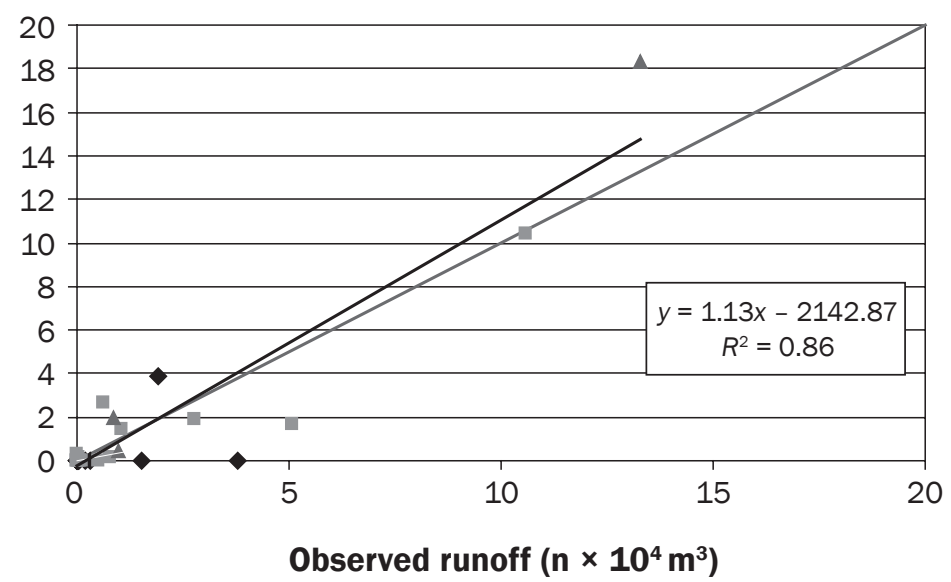

Legend

\section{Table 5}

The discharge, recurrence interval, the duration or times per year, and the annual average outof-bank volume associated with overbank flooding for each location analyzed at Sugar Creek.

\begin{tabular}{|c|c|c|c|c|c|c|}
\hline \multirow{2}{*}{$\begin{array}{l}\text { Stream } \\
\text { distance } \\
(\mathbf{k m})\end{array}$} & \multirow{2}{*}{$\begin{array}{l}\text { Over bank } \\
\text { discharge } \\
\left(m^{3} s^{1}\right)\end{array}$} & \multirow{2}{*}{$\begin{array}{l}\text { Recurrence } \\
\text { interval } \\
\text { (y) }\end{array}$} & \multicolumn{3}{|c|}{ Frequency of over bank discharges } & \multirow{2}{*}{$\begin{array}{l}\text { Overbank } \\
\text { volume } \\
\text { (\%) }\end{array}$} \\
\hline & & & $\begin{array}{l}\begin{array}{l}\text { Time } \\
(\%)\end{array} \\
\end{array}$ & $\begin{array}{l}\text { Times per } \\
\text { year }(n)\end{array}$ & $\begin{array}{l}\text { Times in } \\
2005\end{array}$ & \\
\hline 0.16 & 0.3 & 0.1 & 5 & 18 & 15 & 13 \\
\hline 0.31 & 0.6 & 0.2 & 3.2 & 12 & 11 & 8 \\
\hline 0.95 & 1.6 & 0.5 & 1.4 & 4 & 5 & 3 \\
\hline 3.09 & 1.2 & 0.5 & 1.4 & 5 & 5 & 3 \\
\hline 3.44 & 0.9 & 0.4 & 1.7 & 6 & 6 & 4 \\
\hline 4.65 & 2.3 & 1.4 & 0.2 & 1 & 0 & 1 \\
\hline 4.84 & 2.6 & 1.8 & 0.2 & 1 & 0 & $<1$ \\
\hline 5.23 & 0.6 & 0.4 & 1.4 & 5 & 6 & 4 \\
\hline
\end{tabular}

that the channels are in dynamic equilibrium and maintain their current dimensions.

The recurrence intervals associated with bankfull discharges were in agreement with other recurrence interval estimates for Ohio streams. A study conducted by the USGS found that bankfull discharge recurrence intervals less than 1.1 year are associated with streams with entrenchment ratios greater than 6.3 (Sherwood and Huitger 2005). Powell et al. (2006) estimated that bankfull discharge for large rivers in Ohio are exceeded 1 to 24 times annually and probably more frequently for small streams. In a headwater stream in Ohio, which was impacted by channelization and agricultural activities, Gorney et al. (2011) found that the bankfull discharge varied from 0.2 to 3.6 years with a mean of 1 year.

The annual average overbank volumes correspond with Leopold (1994), who stated that only $5 \%$ of the total flow volume exceeds the bankfull discharge. The average annual volume of overbank flows at the majority of Sugar Creek sites were 1\% to $4 \%$ of total flow volume, and the highest average annual values ( $8 \%$ and $13 \%$ ) occurred at the locations nearest the outlet of the watershed. Visual observations and the weight of quantitative evidence indicate that channel system scour was not a major problem in most locations, and to a large extent, the system was in dynamic equilibrium. We attribute this to good connectivity to a low, active floodplain vegetated with grass, brush, and trees.

\section{Summary and Conclusions}

The combined knowledge of the geomorphology and flooding characteristics of Sugar Creek provided insight on whether further research on the water quality benefits of an active floodplain in the Sugar Creek Watershed should be pursued. In some locations, only a very small fraction of the total volume was estimated to exceed the top of the bank, but at the furthest downstream location, the largest percentage of out-of-bank flow volumes were estimated and amounted to $13 \%$ of the annual discharge volume. Additional research would be needed to determine whether the size of the floodplains and benches, the frequency of flow onto these features, and the annual duration of saturated conditions in these features would result in useful reduction in nutrient exports and/or would be adequate for the stream geomorphology to be self-sustaining. 


\section{References}

Arcement, G.J., and Schneider,V.R. 1989. Guide for selecting Manning's roughness coefficients for natural channels and flood plains. USGS Water-Supply Paper 2339:1-38.

Barkau, R.L. 1993. UNET: One-Dimensional Unsteady Flow through a Full Network of Open Channels: Users Manual. US Army Corps of Engineers, Hydrologic Engineering Center. Davis, CA: US Army Corps of Engineers.

Bowen, Z.H., K.D. Bovee, and T.J. Waddle. 2003. Effects of flow regulation on shallow-water habitat dynamics and floodplain connectivity. Transactions of the American Fisheries Society 132:809-823.

Bradley, A.A., and K.W. Potter. 1992. Flood frequency analysis of simulated flows. Water Resources Research 28:2375-2385.

Brannan, K.M., S. Mostaghimi, P.W. McClellan, S. Inamdar. 2000. Animal waste BMP impacts on sediment and nutrient losses in runoff from the Owl Run watershed. Transactions of the American Society of Agricultural Engineers 43:1155-1166.

Brunner, G.W. 2002. HEC-RAS River Analysis System: Hydraulic Reference Manual. US Army Corps of Engineers Hydrologic Engineering Center. Davis, CA: US Army Corps of Engineers.

Dillaha, T.A., R.B. Reneau, S. Mostaghimi, and D. Lee. 1989. Vegetative filter strips for agricultural nonpoint source pollution control. Transactions of the American Society of Agricultural Engineers 32:513-519.

Dosskey, M.G. 2001. Toward quantifying water pollution abatement in response to installing buffers on crop land. Environmental Management 28:577-598.

Feldman, A.D. 2000. Hydrologic Modeling System HECHMS Technical Reference Manual. US Army Corps of Engineers Hydrologic Engineering Center. Davis, CA: US Army Corps of Engineers.

Gorney, R.M., D.R. Ferris, A.D. Ward, and L.R. Williams. 2011. Assessing channel-forming characteristics of an impacted headwater stream in Ohio, USA. Ecological Engineering 37(2011):418-430.

Haan, C.T. 2002. Statistical Methods in Hydrology, 2nd Ed. Ames, IA: Iowa State University Press.

Dyhouse, G., J. Hatchett, and J. Benn. 2003. Floodplain Modeling Using HEC-RAS. Waterbury, CT: Haestad Press.

Harrelson, C.C., C.L. Rawlins, and J.P. Potyondy. 1994. Stream Channel Reference Sites: An Illustrated Guide to Field Technique. USDA Forest Service, General Technical Report RM-245, Fort Collins, CO: USDA Forest Service.

Jayakaran, A., D. Mecklenburg, A. Ward, and L. Brown. 2005. The formation of fluvial benches in headwater channels in the Midwestern region of the USA. International Journal of Agricultural Engineering 14(4):193-208.

Junk, W.J., P.B. Bayley, and R.E. Sparks. 1989. The flood pulse concept in river-floodplain systems. Canadian
Special Publication of Fisheries and Aquatic Science 106:110-127.

Kallio, S., A. Ward, J.L. D'Ambrosio, and J.D. Witter. 2010. Beyond the field: A look at agricultural ditch floodplains as a water quality BMP. In Proceedings XVIIth World Congress of the International Commission of Agricultural Engineering. American Society of Agricultural and Biological Engineers 9th International Drainage Symposium. June 13, Quebec City, Canada: American Society of Agricultural and Biological Engineers. https://www.bioeng.ca/ publications $/$ meetings-papers?sobi2 Task $=$ sobi2Details \&sobi2 $\mathrm{Id}=83$.

King, K.W., P.C. Smiley,Jr., N.R. Fausey, and B.J. Baker. 2008. Validation of paired watersheds for assessing conservation practices in Upper Big Walnut Creek watershed, Ohio. Journal of Soil and Water Conservation 63(6):380-395, doi:10.2489/jswc.63.6.380.

Koltun, G.F. 2003. Techniques for Estimating Flood-Peak Discharges of Rural, Unregulated Streams in Ohio, 2nd Edition. US Geological Survey, Water Resources Investigations Report 03-4164. Washington, DC: US Department of the Interior, US Geological Survey.

Lee, K.,T.M. Isenhart, R.C. Schultz, and S.K. Mickelson. 2000. Multispecies riparian buffers trap sediment and nutrients during rainfall simulations. Journal of Environmental Quality 29:1200-1205.

Leopold, L.B. 1994. A View of the River. Cambridge, MA: Harvard University Press.

Mecklenburg, D., and A. Ward. 2004. STREAM modules: Spreadsheet tools for river evaluation, assessment, and monitoring. In Proceedings of the American Society of Agricultural Engineers Specialty Conference, Self Sustaining Solutions for Streams, Watersheds, and Wetlands, 312-322. St. Paul, MN, September 12-15, 2004. St. Joseph, MI:American Society of Agricultural Engineers.

Mockus, V. 1960. Selecting a flood frequency method. Transactions of the American Society of Agricultural Engineers 3(1):48-54.

Novotny, V. 2003. Water Quality: Diffuse Pollution and Watershed Management. Second Edition. Boston, MA: John Wiley \& Sons Inc.

Palone, R.S., and A.H. Todd (ed.) 1997. Chesapeake Bay Riparian Handbook: A Guide for Establishing and Maintaining Riparian Forest Buffers. USDA Forest Service. NA-TP-02-97. Radnor, PA: USDA Forest Service.

Pinay, G., J.C. Clement, and R.J. Naiman. 2002. Basic principles and ecological consequences of changing water regimes on nitrogen cycling in fluvial systems. Environmental Management 30:481-491.

Poff. L.N., J.D. Allan, M.B. Bain, J.R. Karr, K.L. Prestegaard, B.D. Richter, R.E. Sparks, and J.C. Stromberg. 1997.The natural flow regime: A paradigm for river conservation and restoration. BioScience 47(11):769-784.
Powell, G.E., D. Mecklenburg, and A. Ward. 2006. Evaluating channel-forming discharges: A study of large rivers in Ohio. Transactions of the American Society of Agricultural and Biological Engineers 49(1):35-46.

Power, M.E., G. Parker,W.E. Dietrich, and A. Sun. 1995. How does floodplain width affect floodplain river ecology? Geomorphology 13:301-317.

Richardson, C.W., Bucks, D.A., and Sadler, E.J. 2008. The conservation effects assessment project benchmark watersheds: Synthesis of preliminary findings. Journal of Soil and Water Conservation 63:590-604, doi:10.2489/ jswc.63.6.590.

Robertson, A.I., P. Bacon, and G. Heagney. 2001. The responses of floodplain primary production to flood frequency and timing. Journal of Applied Ecology 38:126-136.

Rosgen, D.L. 1994. A classification of natural rivers. Catena 22:169-199.

Scharffenberg, W.A., and M.J. Fleming. 2005. Hydrologic Modeling System HEC-HMS: User's Manual. US Army Corps of Engineers Hydrologic Engineering Center. Davis, CA: US Army Corps of Engineers.

Sherwood, J.M., and C.A. Huitger. 2005. Bankfull Characteristics of Ohio Streams and their relation to Peak Streamflows. US Geological Survey, Scientific Investigations Report 2005-5153. Washington, DC: US Department of the Interior, US Geological Survey.

Shome, M.L., and P.M. Steffler. 2006. Flood plain filling by a monoclinal flood wave. Journal of Hydraulic Engineering 132:529-532.

Simon, A., W. Dickerson, and A. Heins. 2004. Suspendedsediment transport rates at the 1.5-year recurrence interval for ecoregions of the United States: Transport conditions at the bankfull and effective discharge? Geomorphology 58:243-262.

Strock, J.S., P.M. Porter, and M.P. Russelle. 2004. Cover cropping to reduce nitrate loss through subsurface drainage in the northern US corn belt. Journal of Environmental Quality 33:1010-1016.

Sveinsson, O.G.B.,J.D. Salas, and D.C.Boes.2003. Uncertainty of quantile estimators using the population index flood method. Water Resources Research 39(8):1206

Ward,A.D., and S.W.Trimble. 2004. Environmental Hydrology. 2nd Edition. Boca Raton, FL: CRC Lewis Press.

Witter, J.D. 2006. Water Quality, Geomorphology, and Aquatic Life Assessments for the Olentangy River TMDL evaluation. Doctoral Dissertation, The Ohio State University, $\mathrm{OH}$. 